hundred feet higher than Kiyanja and situated north-west of it. They have no connection with the Mubuku Glacier."

Mr. Freshfield finds that a rough sketch plan of the snowy group, sent by Signor Sclla, coincides closely with the diagram of Lieut. Behrens, R.E., published in the Geographical Journal for July last, and concludes that "there seems little doubt that the highest summits measured by our engineers are identical with the Duke of the Abruzzi's Ruwenzori." Hence the height of the Ruwenzori range may be taken as 16,625 feet.

The chief topographical discovery made by the Italian expedition, apart from its mountaineering successes, seems to be that the northern fork of the Mubuku, called by Signor Sella the Bugiogo, is of hitherto unsuspected importance. Its stream flows round a bend, which conceals its sources from the lower valley. Beyond this lies a basin penetrating far into the heart of the chain, at the head of which, and on the actual watershed, the highest peaks stand.

\section{THE TORONTO MEETING OF THE BRITISH} MEDICAL ASSOCIATION.

[HE annual meeting of the British Medical Association, held on August $2 \mathrm{I}^{-25}$ at Toronto by invitation of the Canadian Branch, under the presidency of Dr. Reeve, the dean of the medical faculty of the university, was a marked success. The city is a fine one, and the university buildings in the Queen's Park are admirably adapted for the work of a congress, combining convenience and beautiful surroundings. About 1600 members and visitor attended, the British contingent numbering 200 or thereabouts. Canadian hospitality was lavish, and we all carry back pleasant memories of our visit to this great country. In addition, good work was done, and the attendance at the numerous sections was well maintained.

A combined mecting of the sections of physiology and pathology discussed the pathology and physiology of the cell nucleus. The discussion was opened by Prof. Adami, of McGill, in a paper giving an excellent survey of the subject. The conclusions formulated were that (I) the nuclear matter conveys and determines, or controls, the inherited peculiarities of the individual, this conveyance being through matter contained in the chromatin loops or chromosomes, while it may be that these individual loops, varying among themselves, determine particular conditions (2) the nucleus is essential, not merely for the vegetative activities, but also for the higher metabolic activities of the cell and their due coordination; (3) the nucleus is not merely the vegetative centre of the cell, but is involved in its functional activities; (4) the higher syntheses, those associated with growth and those governing specific cellular enzyme actions, are determined and initiated by the nuclear matter; (5) the nucleus is the centre or source of the higher cellular activities, and the nuclear material possesses in itself potentialities superior to those of any ordinary constituent of the cell body; $(6)$ the presence of preformed cytoplasm is essential for the continued existence and growth of the nucleus-each becomes essential for the continued existence of the cell as a whole.

Dr. Ford (Johns Hopkins University) read a paper on an antitoxin for poisonous fungi. $\mathrm{He}$ concluded that the toxic agent of the amonita was of the nature of a glucoside, and that an antitoxic serum could be prepared with it. It was pointed out in the discussion that this idea was somewhat revolutionary, as hitherto it had been impossible to obtain with glucosides an antitoxic substance.

Several papers were read on cancer. Dr. Clowes (Buffalo) had found that in experimental cancer in mice spontaneous recovery often occurred, and that such animals are immune to further inoculation. This was confirmed by Dr. Bashford (London), who stated that there is no evidence that cancer is on the increase, nor that it is endemic in districts. He had never obtained any transference by mere contact, i.e. cancer is not contagious. Prof. Gaylord (Buffalo) detailed some remarkable instances which seemed to show that certain malignant tumours in rats and mice are contagious. As a result of the discussions on cancer, it is noteworthy that the parasitic theory of the origin of cancer seems almost to have been abandoned by pathologists.

NO. I 925 , vOL. 74$]$
Prof. Hewlett and Dr. de Korté (London) read a paper on a beri-beri-like disease occurring in monkeys. The facts observed suggested that beri-beri is an infective disease due to a protozoan parasite, and conveyed by urinary infection. Dr. Ruffer (Egypt) detailed observations on the occurrence of organisms indistinguishable from the cholera vibrio in persons who had not been in contact with cholera.

Prof. Woodhead (Cambridge) stated that he had found opsonins in varying quantity in different milks, facts suggestive of certain lines with regard to treatment.

A combined discussion between the sections of physiology and medicine on over-nutrition and under-nutrition, with special reference to proteid metabolism, was opened by Prof. Chittenden (Yale). As is well known, Prof. Chittenden suggests that half the proteid usually regarded as necessary to support physiological equilibrium is all that is required. Prof. Halliburton (London) did not think that the experiments were conclusive, and suggested that the minimum diet of Prof. Chittenden did not leave anv margin for that "reserve force" so necessary to ward off attacks of disease. It might be that in the excess of proteid beyond that required to maintain physiological equilibrium there might be traces of substances which yielded this reserve force. Dr. Robert Hutchison (London) considered that the proteid question could only be solved by cooperation between physiologists and physicians. We wanted to know, not the proteid minimum, but the proteid optimum. There was a danger in sailing too near the wind; we could get along with one lung or one kidney, but two of either organ were preferable. High feeding is responsible for cure in tuberculosis and neurasthenia.

The address in surgery was delivered by Sir Victor Horsley, who took as his subject the technique of operations on the central nervous system. He showed how, by means of Prof. Vernon Harcourt's inhaler, chloroform could be administered in known amount up to 2 per cent. that during some period of the operation the amount of chloroform could be reduced to 0.5 per cent., and that the administration of oxygen stopped venous oozing.

The Senate of Toronto University conferred the honorary degree of LL.D. on, among others, Sir W. Broadbent Bart., Sir Thomas Barlow, Bart., Sir James Barr, Sir Victor Horsley, Prof. Clifford Allbutt, Prof. Halliburton, Dr. Donald Macalister, and Prof. Aschoff, of Freiburg.

\section{R. T. Hewlert.}

\section{A LARCH SAWFLY IN CUMBERLAND.}

THE Board of Agriculture and Fisheries recently directed attention in the Press and its journal to the attack of the sawfly (Nematus erichsoni, Hartmann) upon larches. So far, serious damage has only been reported to the Board from Cumberland, where the health, if not the life, of an extensive plantation is said to be in danger. This insect is commoner than is supposed, but does not, as a rule, occur in large numbers in this country. There are very few collectors of these insects, hence we are apt to look upon species as rare which really have a wide distribution.

Cameron, in his work on British "Phytophagous Hymenoptera" (vol. ii., p. 51, 1885 ), only records the insect from an unknown locality. Dale mentions it as occurring at Glanvilles Wootton. It has also been seen on larches near Esher, at Wye, Great Staughton, and Budleigh Salterton. It is widely distributed over Europe, where it is now and then sufficiently abundant to become harmful, especially in Germany. Hagen also records it from the United States.

The adult sawfly has a black thorax, the abdomen red, with the basal seventh and ninth segments black. The legs are dull reddish, with most of the tibiæ white, and the posterior feet and apex of the femora black. In length it is about half an inch. The male has not, apparently, been described.

The larvæ are nearly three-quarters of an inch long when mature, and feed upon the leaves from the beginning of July to the end of August. In colour they are shiny grey or dark grey, with the back darker grey except on the second segment. The skin is covered with short, black 
tubercles, and the spiracles show as brown spots. The legs are spotted with black, and the head is shiny black.

When mature the larvæ fall to the ground and spin their cocoons amongst moss, grass, \&c., beneath the trees. The cocoons are more or less cylindrical in form and brown in colour. Many may occur close together. Fortunately these larvæ are preyed upon by several hymenopterous parasites. It is probably these that cause its sudden disappearance in localities where it has occurred. It is, nevertheless, as the Board of Agriculture advises, " of the utmost importance that outbreaks should be discovered at an early stage so that they may be suppressed while still of restricted extent"-an axiom that applies to all insects and fungi that are likely to cause harm to man's crops, trees, or stock.

The Board is preparing an illustrated account of this insect, which will be published in the October issue of its journal. Many such isolated outbreaks of insect pests of greater importance might with advantage be treated in a similar manner.

F. V. T.

\section{SOME RECENT PALAEONTOLOGICAL PAPERS.}

DURING the wide range of field-observation covered by the Austrian Geological Survey, numerous new localities for fossils come to light, while the collections brought to Vienna from outside the Empire furnish the members of the Reichsanstalt with rich material for comparison. R. J. Schubert (Jahrbuch der k.k. geol. Reichsanstalt, I905, p. 6r3) has continued his comprehensive research on the otoliths of fishes, which is finely illustrated with photographic plates. In the Verhandlungen of the same body (1906, p. I24) he summarises his results, which are shown to have a bearing on the geographical conditions of Miocene and Pliocene times in Europe. For instance, in accordance with what we know of the Congeria-beds, the otoliths in these strata are found to belong to the Sciænidæ, a family haunting especially the mouths of large rivers, and even penetrating into fresh water.

Franz Toula (Jahrbuch der Reichsanstalt, 1905, p. 51) also throws new light on the Congeria-beds of Vienna by describing Pelamycybium, a new genus of fish, which has been discovered in them. He discusses a wide range of literature on allied forms of tunny. In the current volume for 1906, p. I, O. Abel investigates the fishes with greatly developed fins that have been recorded from various formations, and states that the Triassic genera Thoracopterus, Bronn., Gigantopterus, and Dollopterus are the only ones that can be referred with certainty to the flyingfish. The two last-named genera are new to science. All these fossil forms are constructed outwardly on the type of the modern Exocœtus. The species of Chirothrix with large fins, and other members of Smith Woodward's Chirothricidæ, are believed by Abel to have been incapable of flight. It is hard, moreover, to have to note that a species known as Engraulis evolans is similarly rejected. Zoologists will be interested in the general discussion of the flight of fishes and its origin (pp. 55-84), and the comparison between true flying-fish and others with expanded pectoral or ventral fins. The author, to avoid misconception, would prefer to speak of "parachute-fish" rather than of "flying-fish." There is no indication that any fossil example used its pectoral fins more effectively for flight than is the case in modern times. The memoir is fully illustrated; and the realisation of flying-fish gleaming in the Triassic sunlight adds a new fascination to the ancient European sea.

G. Stache (Verhandlungen, ibid., 1905, p. 292) directs the attention of zoologists as well as palæontologists to his Sontiochelys, a new chelonian from the Cretaceous of Görz, the affinities of which are with living forms in Australia and Brazil, rather than with fossil Jurassic forms in Europe.

O. Abel (Jahrbuch, ibid., 1905, p. 375) has described a cetacean, Palaeophocaena andrussovi, from the Middle Miocene of the Taman peninsula in the Black Sea. This early form has led him to examine the living Phocæna of NO. I925, VOL. 7t] the Black Sea, and to assign to it the specific name relicta The author points out the differences between it and $P h$. communis, and urges that it arose in the Black Sea area as a direct descendant of the Miocene type. Phocæna is absent from the Mediterranean, while the two dolphins found with it in the Black Sea, Tursiops tursio and Delphinus delphis, abound there, and Herr Abel is thus supplied with additional grounds for his contention. $\mathrm{He}$ also describes ( $\mathrm{p}$. 393) a Miocene transitional form between Halitherium and Metaxytherium.

Passing to the primates, we note that Prof. Rzehak (Verhandlungen, ibid., 1905, p. 329) gives a preliminary account of a lower jaw belonging to a being of the Spy and Krapina type, from Ochos, near Brünn in Moravia. Every addition to our knowledge of this early type of man in Europe, Wilser's Homo primigenius, is to be welcomed, especially as it seems not so long ago when the Neanderthal calvarium was the sole representative of the race. The features shown by the lower jaw of a child found in a cave at Shipka, and hitherto regarded as exceptional, are interestingly repeated in that of the aduIt from the Ochos cave.

T. Fuchs (ibid., p. 198) defends the organic character of the honeycomb-markings known as Palæodictyon, in opposition to the views of Capeder in 1904, who reproduced artificially a fairly similar structure.

Prof. Yokoyama sends a paper on Mesozoic plants from Nagato and Bitchu (Journal of the College of Science, Imperial University, Tokyo), illustrated by three beautifully executed plates. The work confirms the author's previously expressed opinion that a Rhætic flora occurs at Yamanoi.

Part iii. of vol. xxxii. of the Records of the Geological Survey of India is mainly concerned with palæontology. Prof. Diener, of Vienna, describes the permo-Carboniferous fauna of the Subansiri valley in Assam, adopting Waagen's term "Anthracolithic" for beds of the two systems considered jointly. Mr. G. E. Pilgrim reviews the distribution of Elephas antiquus, which he regards as having originated in the Pliocene of Europe, reaching India somewhat later in geological time, as glacial con. ditions set in across Europe. In neither area, however (p. 2I8), did it leave any direct descendants. The paper is accompanied by five handsome plates. Prof. Diener, in a second paper, points out that a bed of Triassic limestone in Byans, 3 feet thick, represents the Noric and Carnic faunas, the forms from distinct horizons becoming mixed in so small a thickness of sediment.

\section{UNIVERSITY AND EDUCATIONAL INTE LLIGENCE.}

Prof. Wilhelm Wien, professor of physics in the University of Berlin, has been invited to occupy the physics chair in the University of Berlin, in succession to the late Prof. Drude.

Science states that by the will of the late Mr. T. Kearney, of Freno, his entire estate, amounting to about $200,000 l$., is bequeathed to the department of agriculture of the University of California.

THE authorities of the Leland Stanford University, which suffered severely through the San Francisco earthquake, are reported to have decided to sell the jewels of Mrs. Leland Stanford, bequeathed to them by their late owner for the purpose of restoring the University library; the value of the jewels is estimated at a million dollars.

BIRKBECK COLLEGE will commence its eighty-fourth session on Wednesday, September 26, when Sir Edward H. Busk, Vice-Chancellor of the University of London, will give the opening address. The college has added considerably to its appliances in recent years, and the physical, chemical, biological, and metallurgical laboratories are weil equipped. Courses in mining, metallurgy, and assaying are given both in the day and evening.

THE council of University College, Bristol, has offered the chair of chemistry, just vacated by Dr. Travers, F.R.S., to Dr. Francis Francis. Dr. Francis studied at 